\title{
$\ll$ Research Note》 \\ Expression of Prolactin Receptor mRNA in Lactotrophs and Somatotrophs of the Chicken Anterior Pituitary Gland
}

\author{
Hiromi Kaneda, Nobuhiro Nakao, Nobumichi Tsushima and Minoru Tanaka \\ Department of Animal Science, Faculty of Applied Life Science, \\ Nippon Veterinary and Life Science University, Musashino, Tokyo 180-8602, Japan
}

\begin{abstract}
Prolactin (PRL) is a hormone mainly secreted by the anterior pituitary gland. In birds, PRL exerts a variety of physiological functions in target tissues expressing the PRL receptor (PRLR). In chicken, the PRLR mRNA is abundant in the anterior pituitary gland, but its regional and cellular localization are unknown. In the present study, we investigated the expression of the PRLR mRNA in cephalic and caudal lobes of the chicken anterior pituitary gland. Real-time polymerase chain reaction (PCR) revealed high levels of PRLR mRNA in both cephalic and caudal lobes. In situ hybridization revealed that the PRLR mRNA was distributed in a wide area of both lobes, and co-localized with the $P R L$ and growth hormone $(G H)$ mRNAs in the cephalic and caudal lobes, respectively. These results suggest that PRL exerts autocrine/paracrine effects through PRLR on PRL-producing lactotrophs and GH-producing somatotrophs in the chicken anterior pituitary gland.
\end{abstract}

Key words: chicken anterior pituitary gland, growth hormone, mRNA expression, prolactin, prolactin receptor

$$
\text { J. Poult. Sci., 55: 150-154, } 2018
$$

\section{Introduction}

Prolactin (PRL) is a hormone secreted by the anterior pituitary gland that participates in a variety of physiological functions in vertebrates (Bole-Feysot et al., 1998). In birds, prolactin is involved in osmoregulation (Harvey et al., 1984; Murphy et al., 1986), crop milk production (Scanes et al., 1975), brood patch formation (Hutchinson et al., 1967), and incubation behavior (Saeki and Tanabe, 1955; March et al., 1994). These functions of PRL are mediated through the PRL receptor (PRLR) in target cells.

Studies showed that the PRLR mRNA is abundantly expressed in the anterior pituitary of laying White Leghorn and Bantam hens (Ohkubo et al., 1998a). The chicken anterior pituitary gland is composed of two lobes, namely, the cephalic and caudal lobes. Six types of endocrine cells are variably distributed in these two lobes, such as the PRLproducing lactotrophs, growth hormone $(\mathrm{GH})$-secreting somatotrophs, thyroid-stimulating hormone (TSH)-producing thyrotrophs, adrenocorticotropic hormone (ACTH)-producing corticotrophs, and follicle-stimulating hormone (FSH) or luteinizing hormone (LH)-secreting gonadotrophs (Kansaku et al., 1995; Proudman et al., 1999; Chowdhury et al., 2003).

Received: May 22, 2017, Accepted: August 29, 2017

Released Online Advance Publication: October 25, 2017

Correspondence: Nobuhiro Nakao, Department of Animal Science, Faculty of Applied Life Science, Nippon Veterinary and Life Science University, Musashino, Tokyo 180-8602, Japan. (E-mail: nakao@nvlu.ac.jp)
However, the regional and cellular localization of the PRLR mRNA in chicken anterior pituitary gland has not been reported. Therefore, the objective of this study is to determine the expression of the PRLR mRNA in lactotrophs and somatotrophs of chicken anterior pituitary gland.

\section{Materials and Methods}

\section{Experimental Birds and Tissue Collection}

Laying White Leghorn hens (10-months-old) were obtained from Santoku Farm Matsuo Corp. (Chiba, Japan). The hens were housed under $16.5 \mathrm{~h}$ light and $7.5 \mathrm{~h}$ dark conditions. Food and water were provided ad libitum. Tissues were isolated after decapitation. For RNA preparation, tissues were immediately frozen in liquid nitrogen. For in situ hybridization, the anterior pituitary glands were frozen in dry ice powders. The frozen tissues were stored at $-80^{\circ} \mathrm{C}$ until further use. All procedures were conducted in accordance with the provision for animal welfare of the Nippon Veterinary and Life Science University (Approval number: 27K44).

\section{RNA Preparation and cDNA Synthesis}

Total RNA was extracted from the tissue using the TRIzol reagent (Life Technologies, Tokyo, Japan) and was reversetranscribed at $50^{\circ} \mathrm{C}$ for 60 min with Superscript III transcriptase (Life Technologies). The resulting cDNA was amplified by PCR using LA Taq polymerase with GC buffer (Takara, Tokyo, Japan). PCR was performed for 33 cycles of $94^{\circ} \mathrm{C}$ for $30 \mathrm{~s}, 60^{\circ} \mathrm{C}$ for $30 \mathrm{~s}$, and $72^{\circ} \mathrm{C}$ for $2 \mathrm{~min}$ using 
Table 1. Primers used for PCR

\begin{tabular}{|c|c|c|c|c|}
\hline cDNA & & Sequence $\left(5^{\prime}-3^{\prime}\right)$ & Size (bp) & Accession No. \\
\hline \multirow[t]{2}{*}{$P R L R^{*}$} & Forward & AGGAAACATTTACCTGTTGGT & 371 & NM_204854.1 \\
\hline & Reverse & AAGCCATCCAGATCTGACATC & & \\
\hline \multirow[t]{2}{*}{$P R L R^{\dagger}$} & Forward & AGGAAACATTTACCTGTTGGT & 628 & NM_204854.1 \\
\hline & Reverse & CATATGAGAGATGATAAGACACCC & & \\
\hline \multirow[t]{2}{*}{$P R L^{\dagger}$} & Forward & GATGAACGTTATGCTCAGGGTCGGGGTTT & 477 & NM_205466.2 \\
\hline & Reverse & CAATTGCTATCATGGATTAGGCGGCACTT & & \\
\hline \multirow[t]{2}{*}{$G H^{\dagger}$} & Forward & ATGGCTCCAGGCTCGTGGTT & 651 & NM_204359.2 \\
\hline & Reverse & TCAGATGGTGCAGTTGCTCT & & \\
\hline
\end{tabular}

* Applied for real-time PCR. ${ }^{\dagger}$ Applied for RNA probe synthesis

forward and reverse primers specific for each cDNA. The sequences of the primers are shown in Table 1. The amplified cDNA fragments were ligated to pGEM-T Easy plasmid vector (Promega, Madison, WI, USA) and transformed into Escherichia coli. The plasmid DNAs were extracted from the bacteria and purified. Sequencing of the cDNA was performed using the BigDye Terminator v3.1 Cycle Sequencing kit (Life Technologies) with an ABI PRISM 310 genetic analyzer (Life Technologies).

\section{Real-Time PCR}

The plasmid DNA containing PRLR cDNA was used as a standard DNA for real-time PCR with forward and reverse primers. The primer sequences are shown in Table 1. Realtime PCR was conducted in accordance with the manufacturer's instructions for the real-time PCR system 7500 (Life Technologies). The thermal parameters for the PCR were $95^{\circ} \mathrm{C}$ for $15 \mathrm{~s}$ and $60^{\circ} \mathrm{C}$ for $35 \mathrm{~s}$ in $25 \mu \mathrm{L}$ of buffer containing $1 \times$ Platinum SYBR Green qPCR SuperMix-UDG (Life Technologies) and $0.2 \mu \mathrm{M}$ each of forward and reverse primers. Quantitative measurements were performed after establishing a linear amplification curve with the serial dilutions of the PRLR cDNA.

\section{In Situ Hybridization (ISH)}

RNA probes for ISH were synthesized using SP6 or T7 RNA polymerases (Takara, Tokyo, Japan) and plasmid cDNAs as the template. The RNA probe for PRLR mRNA was labeled with digoxigenin-11-uridine- $5^{\prime}$-triphosphate and detected using an HNPP fluorescent detection set (Roche Diagnostics, Tokyo, Japan). The RNA probes for PRL and GH mRNAs were labeled with fluorescein-12-uridine-5' triphosphate (Roche Diagnostics). The synthesis and labeling reactions were performed in accordance with the manufacturer's instructions. These labeled probes were hybridized with frozen sections $(18 \mu \mathrm{m})$ of the anterior pituitary gland prepared using a Leica CM1850 cryostat (Leica Biosystems, Nussloch, Germany). The slide-mounted sections were fixed in 4\% paraformaldehyde (PFA) for $10 \mathrm{~min}$, rinsed thrice in phosphate-buffered saline (PBS), and treated with proteinase $\mathrm{K}$ (Wako Pure Chemical Osaka Japan) $(1 \mu \mathrm{g} / \mathrm{m} l)$ in PBS at $25^{\circ} \mathrm{C}$ for $5 \mathrm{~min}$ and with $2 \mathrm{mg} / \mathrm{mL}$ glycine in PBS at $25^{\circ} \mathrm{C}$ for $10 \mathrm{~min}$. After post-fixing in 4\% PFA for $10 \mathrm{~min}$ and rinsing thrice in PBS, the sections were acetylated with acetic anhydride $(0.125 \%)$ in $100 \mathrm{mM}$ triethanolamine $(\mathrm{pH} 8.0)$ at $25^{\circ} \mathrm{C}$ for $20 \mathrm{~min}$ and prehybridized at $60^{\circ} \mathrm{C}$ for $60 \mathrm{~min}$ with $200 \mu \mathrm{g} / \mathrm{mL}$ yeast tRNA in hybridization buffer containing $50 \%$ formamide, $5 \times$ standard saline citrate (SSC), and 0.5 $\mu \mathrm{g} / \mathrm{mL}$ heparin in a humidity chamber. Both digoxigeninlabeled and fluorescein-labeled probes $(300 \mathrm{ng} / \mathrm{mL}$ each) were added to the hybridization buffer and incubated at $60^{\circ} \mathrm{C}$ for $16 \mathrm{hr}$. After washing with $2 \times \mathrm{SSC} /$ formamide and $0.1 \times$ $\mathrm{SSC}$ at $60^{\circ} \mathrm{C}$, the sections were incubated in a blocking buffer containing casein $(5 \mathrm{mg} / \mathrm{mL})$ and sheep serum $(5 \mu \mathrm{L} / \mathrm{mL})$ at $25^{\circ} \mathrm{C}$ for $30 \mathrm{~min}$. Subsequently, the sections were incubated with anti-digoxigenin antibody conjugated to alkaline phosphatase (Roche Diagnostics) diluted 1:2,000 in the blocking buffer at $4^{\circ} \mathrm{C}$ for $16 \mathrm{hr}$ in the humidity chamber. After washing with buffer containing $100 \mathrm{mM}$ Tris-HCl (pH7.5), 150 $\mathrm{mM} \mathrm{NaCl}$, and $0.05 \%$ Tween 20 , and then with detection buffer containing $100 \mathrm{mM}$ Tris- $\mathrm{HCl}$ (pH8.0), $100 \mathrm{mM} \mathrm{NaCl}$, and $10 \mathrm{mM} \mathrm{MgCl} 2$ at $25^{\circ} \mathrm{C}, 300 \mu \mathrm{L}$ of HNPP/Fast Red solution (Roche Diagnostics) was applied to the sections and incubated at $25^{\circ} \mathrm{C}$ for $30 \mathrm{~min}$. After washing with the washing buffer at $25^{\circ} \mathrm{C}$, the sections were mounted with ProLong Diamond antifade mountant with 4',6-diamidino-2-phenylindole (DAPI) (Life Technology) and air-dried. Red fluorescence of the digoxigenin-labeled probes and green fluorescence of fluorescein-labeled probes were detected using a fluorescence microscope (Axiovert 200M; Carl Zeiss Microscopy, Tokyo, Japan).

\section{Statistical Analysis}

All data were analyzed using one-way analysis of variance, and differences in values were confirmed using the Tukey multiple comparison test. All analyses were performed using GraphPad Prism (GraphPad Software, San Diego, CA, USA).

\section{Results}

\section{Comparison of the PRLR mRNA Levels in the Anterior Pituitary Gland and Other Tissues}

The PRLR mRNA levels in the anterior pituitary gland, liver, kidney, duodenum, jejunum, ileum, ovary, and hypothalamus were determined using real-time PCR. Markedly high levels of PRLR mRNA were observed in both the cephalic and caudal lobes of the anterior pituitary gland than in other tissues. The levels in the cephalic and caudal lobes were almost equivalent and were more than threefold higher 


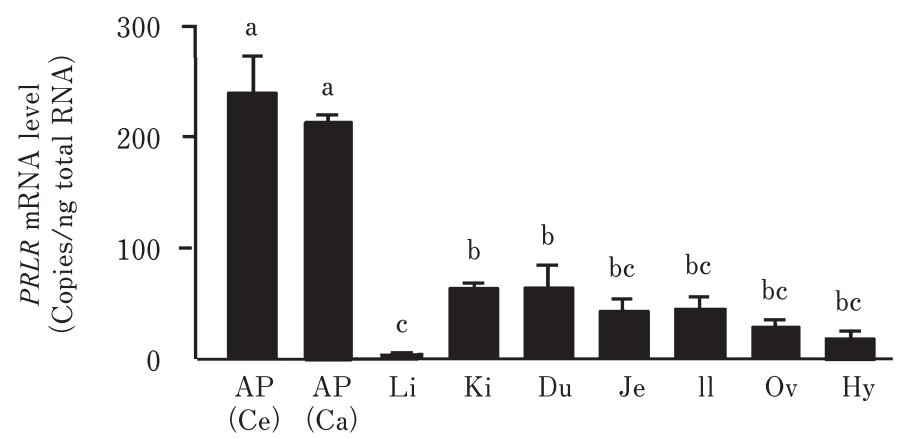

Fig. 1. The PRLR mRNA levels in chicken tissues. The $P R L R$ mRNA levels were measured using real-time PCR. AP, anterior pituitary gland; $\mathrm{Ce}$, cephalic lobe; $\mathrm{Ca}$, caudal lobe; Li, liver; Ki, kidney; Du, duodenum; Je, jejunum; Il, ileum; Ov, ovary; Hy, hypothalamus. Each bar represents the mean \pm SEM $(n=4)$. Bars with different letters are significantly different $(P<0.05)$.

than those of other tissues (Fig. 1).

Regional and Cellular Distribution of PRLR, PRL, and GH $m R N A s$ in the Anterior Pituitary Gland

First, the distribution of PRLR, PRL, and GH mRNAs in the anterior pituitary gland was determined using ISH. As shown in Fig. 2A, fluorescence signals in the entire anterior pituitary gland sections were detected with antisense probes, and not with sense probes, for each mRNA, indicating that the fluorescence signals were derived from $P R L R, P R L$, and $G H$ mRNAs. The fluorescent signal of the PRLR mRNA was distributed in both cephalic and caudal lobes, whereas signals of PRL and GH mRNAs were predominantly detected in the cephalic and caudal lobes, respectively. Figure 2B shows magnified (20-fold) fluorescent images with PRLR and $P R L$ antisense probes in an arbitrary area in the cephalic lobe and with $P R L R$ and $G H$ antisense probes in an arbitrary area in the caudal lobe. The merged fluorescent images of PRLR and PRL or GH mRNAs indicated that the PRLR mRNA was expressed in some of the PRL mRNA-expressing cells in the cephalic lobe and in most $G H$ mRNA-expressing cells in the caudal lobe.

\section{Discussion}

Quantitative real-time PCR analyses revealed abundant expression of the PRLR mRNA in both cephalic and caudal lobes of the chicken anterior pituitary gland. In agreement with these results, ISH analyses revealed extensive expression of the PRLR mRNA in both cephalic and caudal lobes. ISH also showed that the PRL and $G H$ mRNAs were predominantly expressed in the cephalic and caudal lobes, respectively. In the cephalic lobe, the PRLR mRNA was expressed in some of the $P R L$ mRNA-expressing cells, highlighting expression of the PRLR mRNA in other endocrine cells producing TSH, ACTH, FSH, or LH. In support of this observation, PRLR has been detected in all endocrine cells of the rat anterior pituitary gland (Morel et al., 1994). In mammals, PRL is known to inhibit its own synthesis and secretion and stimulate internalization of its receptor in anterior pituitary gland cells (Herbert et al., 1979; Melded et al., 1980; Divots and Boutin, 1999). Co-expression of the PRLR mRNA with $P R L$ mRNA in the chicken anterior pituitary gland cells suggests similar autocrine/paracrine functions of PRL.

Interestingly, the PRLR mRNA was found in $G H$ mRNAexpressing cells of the caudal lobe as well as PRL mRNAexpressing cells of the cephalic lobe. Studies showed that the levels of PRL, GH, and PRLR mRNAs in the chicken anterior pituitary gland increase during late embryonic development and those of the PRL and PRLR mRNAs are higher in incubating hens than in laying hens (Ohkubo et al., 1998b; Kansaku et al., 1994; Leclerc et al., 2007). These findings suggest unknown autocrine/paracrine functions of PRL in lactotrophs and somatotrophs during embryonic development and reproductive stages.

Recently, PRL has been shown to act as an autocrine/paracrine antiproliferative and proapoptotic factor as it inhibits the expression of PRLR in rodent anterior pituitary gland, and this action is considered to be involved in cell turnover and homeostasis of the anterior pituitary gland (Ferraris et al., 2012; Ferraris et al., 2013; Ferraris et al., 2014). Cell proliferation and apoptosis has been observed in the cephalic and caudal lobes of the anterior pituitary gland of turkey hen following nest-deprivation, with decrease in plasma PRL concentration (Rajesh et al., 2001). Similarly, in both cephalic and caudal lobes of the chicken anterior pituitary gland, cell proliferation and apoptosis were observed during inhibition and resumption of laying, which may cause rejuvenation of the anterior pituitary gland (Chowdhury and Yoshimura, 2002). These findings suggest that PRL may be involved in cell turnover in the chicken anterior pituitary gland. Expression of the PRLR mRNA in endocrine cells other than lactotrophs and somatotrophs remains to be investigated. 
A

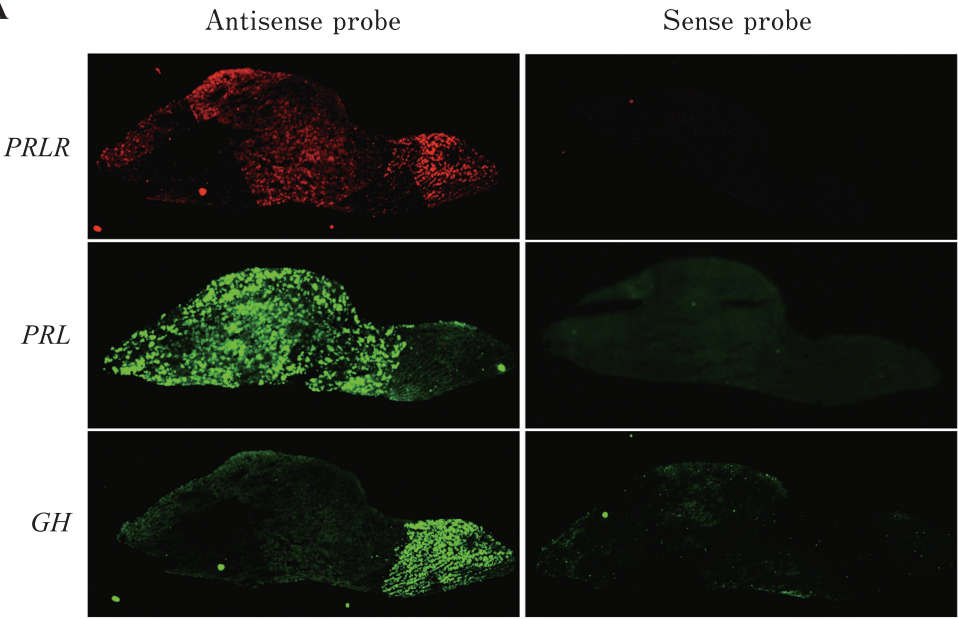

B

Cephalic lobe

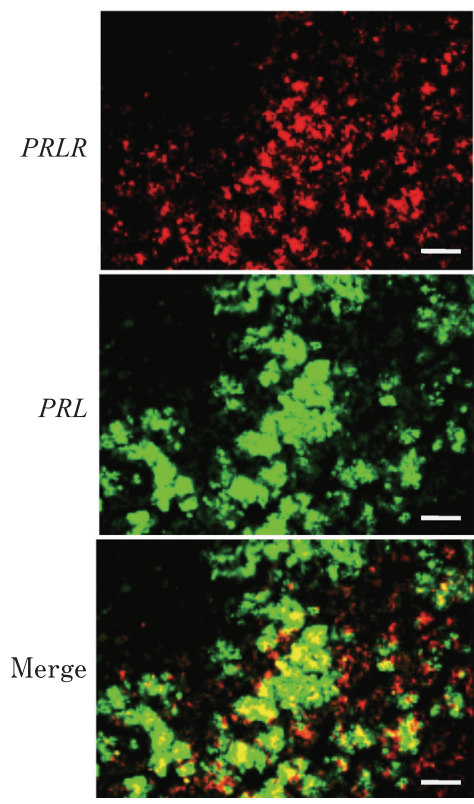

Caudal lobe

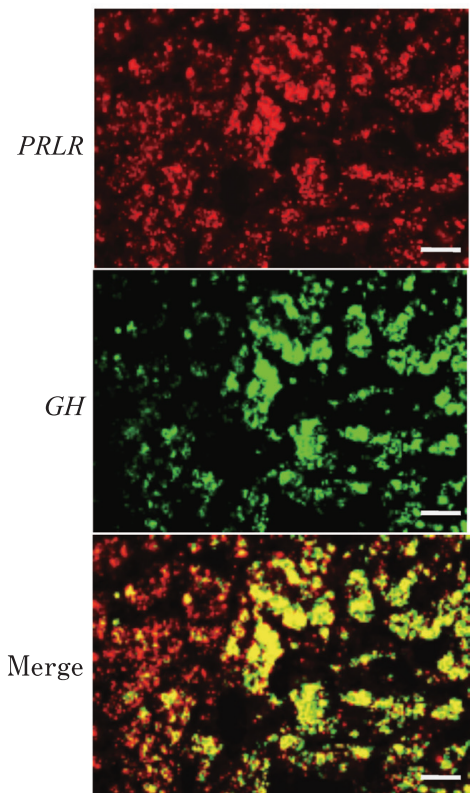

Fig. 2. The distribution of $P R L R, P R L$, and $G H$ mRNAs in the chicken anterior pituitary gland. $P R L R, P R L$, and $G H$ mRNAs were detected by ISH. Red fluorescence of digoxigenin-labeled antisense and sense probes for PRLR mRNA and green fluorescence of fluoresceinlabeled antisense and sense probes for $P R L$ or $G H$ mRNAs were detected using a fluorescence microscope. A: The distribution of $P R L R, P R L$, and $G H$ mRNAs in entire anterior pituitary gland. B: The co-expression of PRLR and PRL mRNAs in an area of the cephalic lobe and PRLR and $G H$ mRNAs in an area of the caudal lobe. Scale bars represent $20 \mu \mathrm{m}$. 


\section{Acknowledgments}

We thank Yoshikazu Tanaka for technical support for fluorescence microscope.

\section{References}

Bole-Feysot C, Goffin V, Every M, Binary N and Kelly PA. Prolactin (PRL) and its receptor: actions, signal transduction pathways and phenotypes observed in PRL receptor knockout mice. Endocrine Reviews, 19: 225-268. 1998.

Chowdhury VS and Yoshimura Y. Cell proliferation and apoptosis in the anterior pituitary of chicken during inhibition and resumption of laying. General and Comparative Endocrinology, 125: 132-141. 2002.

Chowdhury VS and Yoshimura Y. Immunocytochemical identification of Pit-1 containing cells in the anterior pituitary of hens. Journal of Reproduction and Development, 49: 375-379. 2003.

Divots D and Boutin JM. Autoregulation of the rat prolactin gene in lactotrophs. Molecular and Cellular Endocrinology, 158: 99109. 1999.

Ferraris J, Bouillon F, Bernadet M, Seilicovich A, Goffin V and Pisera D. Prolactin receptor antagonism in mouse anterior pituitary: effects on cell turnover and prolactin receptor expression. American Journal of Physiology. Endocrinology and Metabolism, 302: E356-364. 2012.

Ferraris J, Bernichtein S, Pisera D and Goffin V. Use of prolactin receptor antagonist to better understand prolactin regulation of pituitary homeostasis. Neuroendocrinology, 98: 171-179. 2013.

Ferraris J, Zárate S, Jaita G, Bouillon F, Bernadet M, Auffret J, Seilicovich A, Binary N, Goffin V and Pisera D. Prolactin induces apoptosis of lactotropes in female rodents. PLoS One, 9: e97383. 2014.

Herbert DC, Ishikawa H and Runnels EG. Evidence for the autoregulation of hormone secretion by prolactin. Endocrinology, 104: 97-100. 1979.

Hutchison RE, Hinde RA and Steel E. The effects of estrogen, progesterone and prolactin on brood patch formation in ovariectomized canaries. Journal of Endocrinology, 39: 379-385. 1967.

Kansaku N, Shimada K, Terada O and Saito N. Prolactin, growth hormone, and luteinizing hormone-beta subunit gene expression in the cephalic and caudal lobes of the anterior pituitary gland during embryogenesis and different reproductive stages in the chicken. General and Comparative Endocrinology, 96: 197-205. 1994.
Kansaku N, Shimada K and Saito N. Regionalized gene expression of prolactin and growth hormone in the chicken anterior pituitary gland. General and Comparative Endocrinology, 99: 60-68. 1995.

Leclerc B, Zadworny D, Bédécarrats G and Kuhnlein U. Development of a real-time (Q) PCR assay to measure variation in expression of prolactin receptor mRNA in the hypothalamus and pituitary gland during late embryogenesis in turkeys and chickens. General and Comparative Endocrinology, 150: 319325. 2007.

March JB, Sharp PJ, Wilson PW and Sang HM. Effect of active immunization against recombinant-derived chicken prolactin fusion protein on the onset of broodiness and photoinduced egg laying in bantam hens. Journal of Reproduction and Fertility, 101: 227-233. 1994.

Melded S, Carlson HE, Briggs J and Hershman JM. Autofeedback of prolactin in cultured prolactin-secreting pituitary cells. Hormone Research, 12: 340-344. 1980.

Morel G, Ouhtit A and Kelly PA. Prolactin receptor immunoreactivity in rat anterior pituitary. Neuroendocrinology, 59: 78-84. 1994.

Murphy MJ, Brown PS and Brown SC. Osmoregulatory effects of prolactin and growth hormone in embryonic chicks. General and Comparative Endocrinology, 62: 485-492. 1986.

Ohkubo T, Tanaka M, Nakashima K, Talbot RT and Sharp PJ. Prolactin receptor gene expression in the brain and peripheral tissues in broody and nonbroody breeds of domestic hen. General and Comparative Endocrinology, 109: 60-68. 1998a.

Ohkubo T, Tanaka M, Nakashima K and Sharp PJ. Relationship between prolactin receptor mRNA in the anterior pituitary gland and hypothalamus and reproductive state in male and female bantams (Gallus domestics). General and Comparative Endocrinology, 111: 167-176. 1998b.

Proudman JA, Vandesande F and Berghman LR. Immunohistochemical evidence that follicle-stimulating hormone and luteinizing hormone reside in separate cells in the chicken pituitary. Biology of Reproduction, 60: 1324-1328. 1999.

Rajesh R, Kennel WJ and Proudman JA. Increased proliferative activity and programmed cellular death in the turkey hen pituitary gland following interruption of incubation behavior. Biology Reproduction. 64: 611-618. 2001.

Scanes CG, Bolton NJ and Chadwick A. Purification and properties of an avian prolactin. General and Comparative Endocrinology, 27: 371-379. 1975. 